\title{
EARTHQUAKE STUDY IN SOUTHERN CALIFORNIA, 1947
}

\author{
B. Gutenberg and C. F. Richter \\ (Contribution No. 405, Balch Graduate School of the Geological Sciences)
}

This continues the provious report by GUTENBERG and RICHTER [1947]. Papers published during the year are also listed under FU [1047]; RICHTER [1947]; and WOOD [1947].

The book presanting revised study of the selsmicity of the Farth will be published by the Princaton Unlverslty Press. Untll publication, the manuscript will be continuously revised to kceg It up to date.

Ruports on the following research were prepared for the meetings of the Seismological and Geological Soctetles of America at Pasadena in April 1848.

Gutenberg has investigated selsmograms at epicentral distances from four degrees to $26^{\circ}$, constructed revised travel times for $\mathrm{P}$ and $\mathrm{S}$, and determined the amplitudes of both phases as functlons of distance. All observations are explained on the assumption that the velocities of bolh $L^{2}$ and $\mathbf{8}$ decroase by roughly one per ecnt in the depth range below the Mohorovivit discontinulty, reach minima at about $80-100 \mathrm{~km}$ below the surface, and increase agaln at about $150 \mathrm{~km}$ bolow which polsson's ratio remalns near 0.30 , appreclably higher than its values (near 0.25 ) in the upper layers.

J. M. Nordqulst and L. P. Geldart have Investlgated colncidences in calendar date between arthigukes in the sitmo area in different years. Such colncldences, at first sight surprisingly numerous, agrec closely with the theoretical expectancy on the hypothesis of purely random occurrence.

llugo Benloff ts engaged on investlgation of the relense of energy in sequences of earthquakes. Thits includes aftershocks and also the general selsmicity of limited regions, and applies to deep at: will ats los shallow shocks. Prellminary results indleate that ench sequence forms an elastic, plastic, or comblnation elastic-plastic creep series.

C. H. Dix has consulted with those constructing the new electronic digital computer at Princeton, and is considering applications of this and other machines to selsmology and geophysics.

The Manix earthquake [RICHTER, 1947] in the central Mojave Desert, developed fault trace phenomena on a very small scale (displacements of a few inches traceable for two to three mlles) indicating left-hand strike slip on the roughly east-west Manix fault. This feature has been investigated with reference to the regional geology by J. P. Buwalda and C. F. Richter.

The Instrumental records of aftershocks of the Manix earthquake have been studied by Richter and Nordquist. The data clearly indicate a line of epicenters trending slightly south of east from that of the main shock; thls line is transverse to the Manix fault.

Response of the strain selsmometers has been improved by a new transducer, and a second component at right angles to the first strain instrument has been installed.

Physical constants of all the Pasadena instruments have been checked, and some adjustments made. Figure 1 lllustrates the response curves (to continuous sinusoldal waves) for seismometers now in routine service.

Construction has been commenced on a tiltmeter unit.

Routine bulletins for teleselsms and local shocks have been issued through June and December 1947 , respectively. 


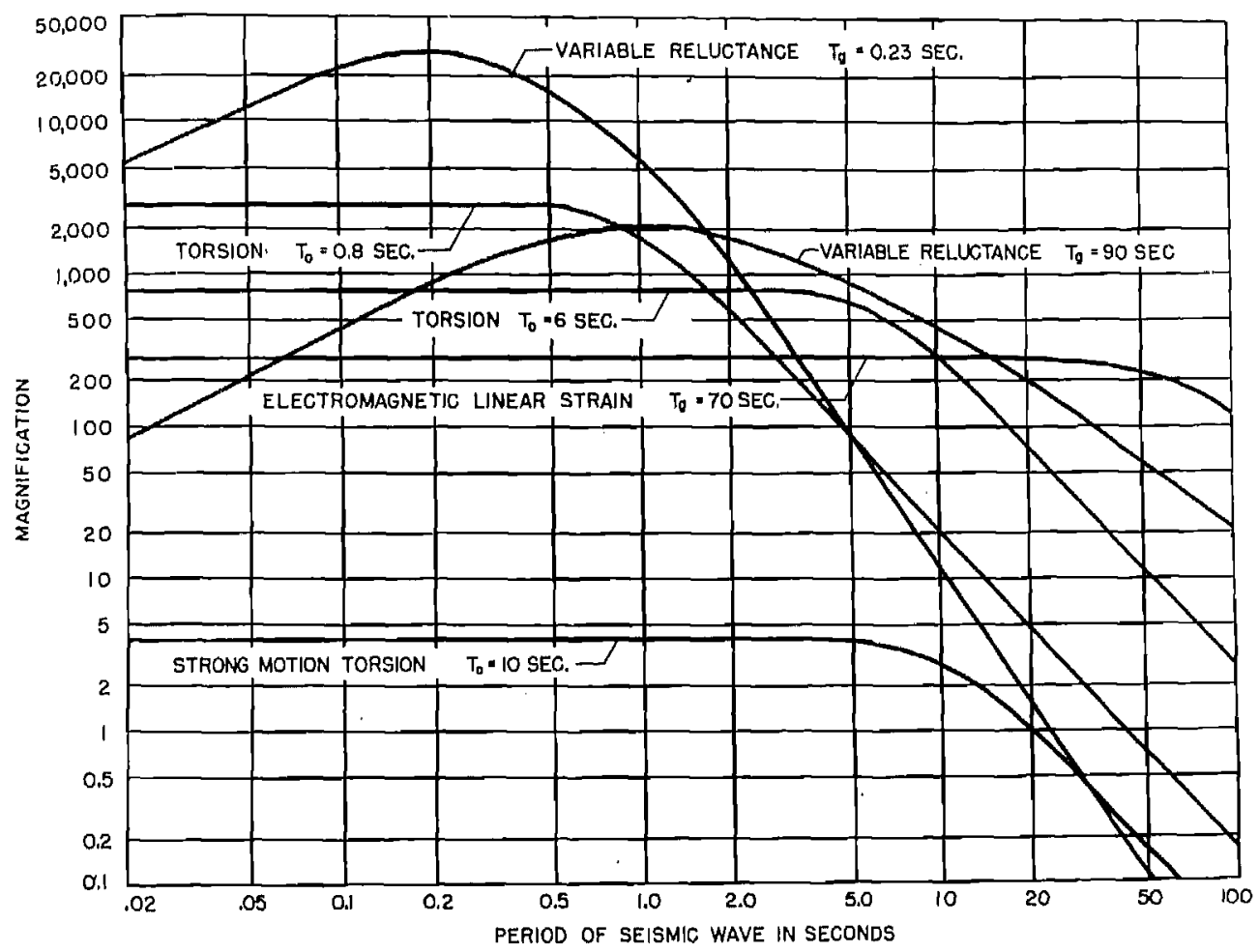

Fig. 1--Standard response curves for instruments in routine service at Pasadena

The most important shocks in the southern Caltfornia area during 1947 were the Manix earthquake of April 10 (magnitude $61 / 2$ or over) and a shock near Morongo Valley on July 24 (magn1tude 5.5).

No great earthquake (magnitude $73 / 4$ or over) occurred anywhere in the World during 1947. The Philippine earthquake of January 24,1948 , was of magnitude $B$ at least.

\section{References}

FU, C. Y., On seismlc rays and waves (Pt. 1), Bull. Seis. Soc. Amer., v. 37, pp. 331-346, 1947 GUTENBERG, B., and RICHTER, C. F., Earthquake study in southern Callfornia, 1946, Trans. Amer. Geophys. Union, v. 28, pp. 633-634, 1947.

RICHTER, C. F., The Manix (California) earthquake of April 10, 1947, Bull, Seism. Soc. Amer., v 37, pp. 171-179, 1947.

WOOD, IJARRY O., Earthquakes in southern California with geological relations (Pts. 1 and 2), Bull. Seis. Soc. Amer., v. 37, pp. 107-157, 217-258 + 4 maps, 1947.

Seismological Laboratory,

220 N. San Rafael Avenue, Pasadena 2, California

(Manuscript received ApriI 5, 1948; presented at the Twenty-Ninth Annual Meeting, Washington, D. C., April 23, 1948; open for formal discussion until November 1, 1948.) 